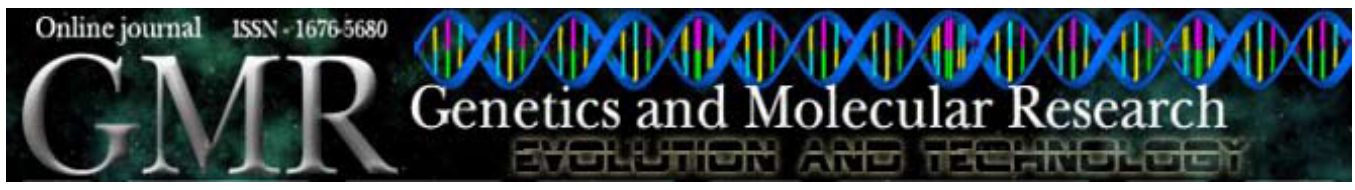

\title{
Infestation by Pyemotes tritici (Acari, Pyemotidae) causes death of stingless bee colonies (Hymenoptera: Meliponina)
}

\author{
C. Menezes ${ }^{1}$, A. Coletto-Silva ${ }^{2}$, G.S. Gazeta ${ }^{3}$ and W.E. Kerr ${ }^{4}$ \\ ${ }^{1}$ Departamento de Biologia, Faculdade de Filosofia, Ciências e Letras de \\ Ribeirão Preto, Universidade de São Paulo, Ribeirão Preto, SP, Brasil \\ ${ }^{2}$ Instituto Nacional de Pesquisas da Amazônia, \\ Coordenação de Pesquisas em Ciências Agronômicas, Manaus, AM, Brasil \\ ${ }^{3}$ Departamento de Entomologia, Laboratório de Ixodides, \\ Instituto Oswaldo Cruz/Fiocruz, Rio de Janeiro, RJ, Brasil \\ ${ }^{4}$ Universidade Federal de Uberlândia, \\ Instituto de Genética e Bioquímica, Uberlândia, MG, Brasil \\ Corresponding author: $\mathrm{C}$. Menezes \\ E-mail: menezes.cristiano@gmail.com
}

Genet. Mol. Res. 8 (2): 630-634 (2009)

Received December 12, 2008

Accepted January 26, 2009

Published June 2, 2009

\begin{abstract}
We report the infestation of stingless bee nests by the mite Pyemotes tritici, which killed four colonies of Tetragonisca angustula and one colony of Frieseomelitta varia in Brazil. The first infected colony, a colony of $T$. angustula, came from an area between Uberlândia and Araguari, Minas Gerais. The transfer of the mites to the other colonies occurred through the transfer of infected combs and subsequent manipulations. Other colonies in the same meliponary, which had not been manipulated, were not infected. The infestation was terminated by isolating the dead colonies from the meliponary.
\end{abstract}

Key words: Mites; Meliponini; Meliponiculture; Apiculture;

Natural enemies 


\section{INTRODUCTION}

Harmonic interactions between mites and stingless bees are known from the scientific literature (Flechtmann and Camargo, 1974; Alford, 1975; Delfinado-Baker et al., 1983; Nogueira-Neto, 1997). Some of these authors suggest that certain species of mites help bees to clean the nest, control other mite populations, or even eliminate pathogenic fungi.

Recently, two reports on mortal infestation of stingless bee colonies of Melipona (Hymenoptera, Apidae, Meliponini) by Pyemotes tritici (Acari: Pyemotidae) have changed our view of harmonic relationships between stingless bees and mites. The first report was on three colonies of Melipona subnitida and M. asilvae at Jardim do Seridó, Rio Grande do Norte, Brazil, which had been infested by mites of P. tritici (Kerr et al., 1996; Nogueira-Neto, 1997). In this case, the mites killed all individuals (adults and immatures), in addition to causing itches and redness of the beekeeper's skin. The second report registered an infestation by the same mites on M. colimana at Autlán de Navarro, Jalisco, Mexico (Macías-Macías and Otero-Colina, 2004). The authors concluded that mites were responsible for the death of the colony, which had recently been transferred from a log to a nest-box.

We describe a third case of mites infesting colonies of the stingless bees Tetragonisca angustula Latreille, 1811, and Frieseomelitta varia Lepeletier, 1836, by the mite P. tritici.

\section{MATERIAL AND METHODS}

Three colonies of T. angustula came from an area between Uberlândia and Araguari, Minas Gerais, Brazil (18 $47^{\prime} 211^{\prime \prime}$ ' 48 $\left.08^{\prime} 550^{\prime \prime} \mathrm{W}\right)$ and had been donated to the Federal University of Uberlândia in October 2005. The colonies were installed in an experimental meliponary, where about 40 colonies of various species of stingless bees were kept. There is no exact information about the methods used to transfer the nests from their natural housing to the nest boxes, but it had been done shortly before transporting them to Uberlândia. As soon as they were installed in the meliponary, the colonies were inspected and fed. All three colonies had a good number of workers and a physogastric queen, which showed normal oviposition behavior. The other two colonies, one of $F$. varia and one of $T$. angustula, were already installed in the meliponary and had been established about six months prior to our observations.

During their management, the colonies that died were observed without help of special equipment. After we concluded that their death had been caused through infestation by mites, all the material from these colonies was taken to the laboratory, where it was analyzed with a stereomicroscope. Photos of the infested material were made with a camera connected to the stereomicroscope. Samples containing mites were fixed in $80 \%$ alcohol solution and transferred to slides for taxonomic analyses (Flechtmann, 1973).

\section{RESULTS AND DISCUSSION}

Approximately 25 days after installing the three new colonies of $T$. angustula in the meliponary, one was found dead. Its entrance tube was closed and the inner structure was intact. All adult individuals including the physogastric queen, as well as a part of the larvae and pupae, were dead, but without clear evidence of the cause of death. The only thing unusual was the presence of very tiny roundish and whitish structures on the dead individuals (Figure 1A). The storage pots were intact and still contained honey and pollen. As we did not 
consider the possibility of a mite infestation at that time, those parts of the combs that still contained living pupae were transferred to another colony of T. angustula (Figure 1B).

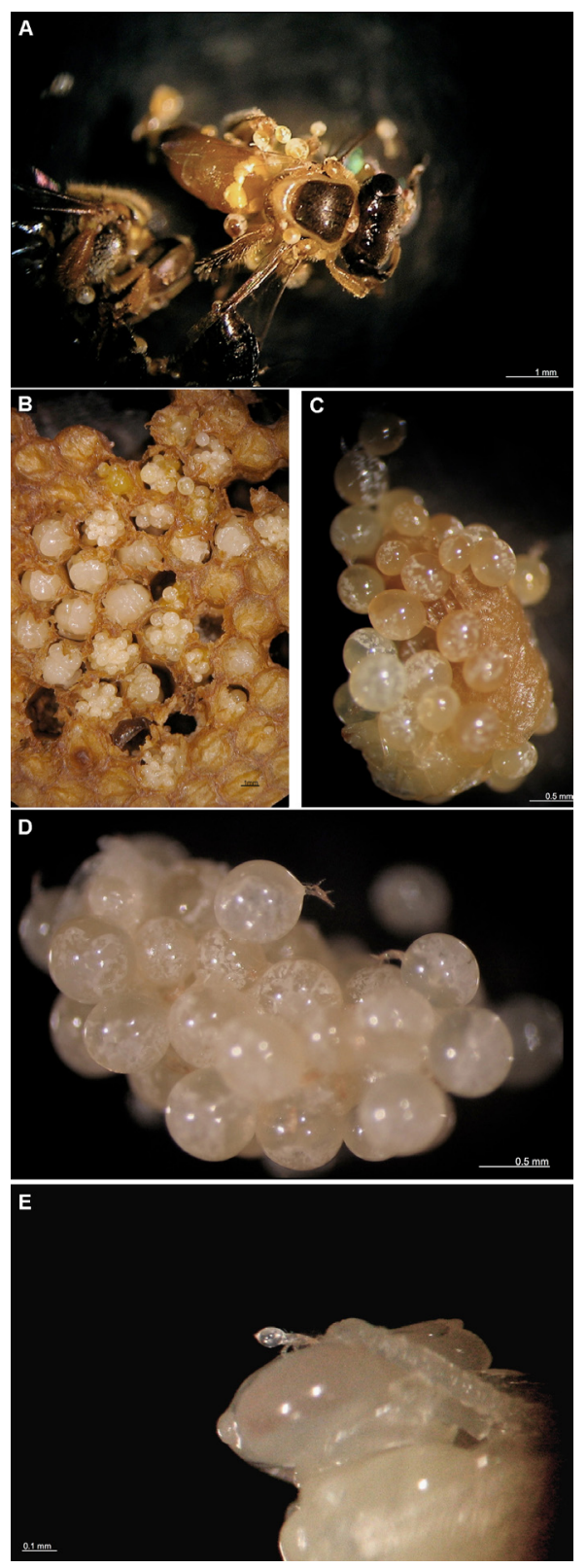

Figure 1. Pyemotes tritici parasitizing the individuals of a colony of Tetragonisca angustula. A. Mites parasitizing at inter-segmental areas of an adult worker. B. Cells of an infested comb were opened to show the mites on pupae. C. Physogastric mites parasitizing a larva. D. Physogastric mites parasitizing a pupa. E. A young mite parasitizing a pupa seen from the side. 
Three days later, the colony that had received the combs was also found dead and the same characteristics as described above were observed inside the hive. Again, the combs that contained living pupa were introduced into two other colonies of T. angustula. Both of them were found dead the next day.

A colony of $F$. varia, which had been manipulated in the meantime, also died. In this case, however, there had been no transfer of material from the infected colonies. We concluded that, in this case, the contamination of the colony happened through mites on the beekeeper's hands. Besides these five colonies, no further colony of the meliponary was affected.

The taxonomic analyses revealed that the mite P. tritici had infested the bee colonies. This is the same species that infested and killed the colonies of stingless bees in the other registered cases in Northeastern Brazil and in Mexico (Kerr et al., 1996; NogueiraNeto, 1997; Macías-Macías and Otero-Colina, 2004).

This mite definitely caused the death of the bee colonies. This conclusion is supported by many types of evidence found in all dead colonies: lack of remnants of other natural enemies, such as ants, cleptoparasitic bees or phorid flies; the dead bees were not injured (Figure 1A); the entrance tube and the inner structure of the colony were intact; many food storage pots were still closed; the number of adult bees before the infestation was certainly large enough to maintain the colony.

The sex ratio of $P$. tritici offspring is 1-5\% males and $95-99 \%$ females, and each female can produce 200-250 new individuals (Bruce, 1984; Bruce and Wrensch, 1990). The quick proliferation, which takes four days from adult to adult, and the sex-ratio, which benefits the production of females, allow small populations to expand to thousands of individuals in a few weeks. We cannot be sure how long it took the first colony to die and at what time it had been infected. But because the initial population of mites might have been smaller, it might have taken longer than in the following colonies, which were probably infected by a huge number of mites when we transferred the combs.

The mites were parasitizing both adult bees and immature individuals (pupae and larvae) (Figure 1C, D and E). Yet, the mite concentration was higher on the larvae and the pupae than on the adult bees. Probably this is because the mites were concentrated at the inter-segmental areas of the adult bees, instead of being distributed over the entire body, as was the case on the larvae and pupae.

There is very little knowledge about the relationship between Pyemotes and bees (reviewed by O'Connor and Klimov, 2004). These mites have been reported to parasitize solitary bees of the Anthophoriidae and Megachilidae families. However, in addition to the other two reports on stingless bees (Kerr et al., 1996; Nogueira-Neto, 1997; MacíasMacías and Otero-Colina, 2004), there are also reports of these mites parasitizing Apis mellifera and A. cerana. The most severe case happened in Queensland, Australia, where Pyemotes mites caused the death of 19 colonies of A. mellifera (Veitch, 1936 apud Morse, 1978).

Apparently, the natural dispersion of the mites is restricted, since, besides those colonies that had been manipulated, no other colonies in the surrounding area were contaminated. The same happened in the other two cases reported for stingless bees (Kerr et al., 1996; Nogueira-Neto, 1997; Macías-Macías and Otero-Colina 2004). Isolating the infested colonies obviously is the most convenient solution to control infestation. 


\section{ACKNOWLEDGMENTS}

We thank Dr. Francis L.W. Ratnieks, Dr. Hayo H.W. Velthuis and Dr. Vera L. Imperatriz-Fonseca, as well other colleagues from the Genetics Laboratory of Uberlândia (INGEB-UFU) and from Ribeirão Preto (FFCLRP-USP) for their valuable suggestions, and Dr. Michael Hrncir for helping in the translation of this report. We also thank Consórcio Capim Branco de Energia (CCBE) for the donation of the stingless bee colonies. Publication supported by FAPESP (\#07/50218-1).

\section{REFERENCES}

Alford DV (1975). Bumblebees. Davis-Poynter Ltd., London.

Bruce WA (1984). Temperature and humidity: effects on survival and fecundity of Pyemotes tritici (Acari: Pyemotidae). Int. J. Acarol. 11: 135-138.

Bruce WA and Wrensch DL (1990). Reproductive potential, sex ratio, and mating efficiency of the straw itch mite (Acari: Pyemotidae). J. Econ. Entomol. 83: 384-391.

Delfinado-Baker M, Baker EW and Roubik DW (1983). New genus and species of Hypoaspidinae (Acari: Laelapidae) from nests of stingless bees. Int. J. Acarol. 9: 195-203.

Flechtmann CHW (1973). Ácaros de Importância Médico Veterinária. Biblioteca Rural, Livraria Nobel S.A., São Paulo.

Flechtmann CHW and Camargo CA (1974). Acari Associated With Stingless Bees (Meliponidae, Hymenoptera) from Brazil. Proceedings of the International Congress of Acarology, Saafelden, 315-319.

Kerr WE, Carvalho GA and Nascimento VA (1996). Abelha Uruçu, Biologia, Manejo e Conservação. Coleção Manejo da Vida Silvestre. Fundação Acangaú, Belo Horizonte.

Macías-Macías JO and Otero-Colina G (2004). Infestation of Pyemotes tritici (Acari: Pyemotidae) on Melipona colimana (Hymenoptera: Apidae: Meliponinae): a case study. Agrociencia 38: 525-528.

Morse RA (1978). Honey Bee Pests, Predators, and Diseases. Cornell University Press, Ithaca.

Nogueira-Neto PN (1997). Vida e Criação de Abelhas Indígenas sem Ferrão. Nogueirapis, São Paulo.

O'Connor B and Klimov P (2004). Family Pyemotidae Berlese, 1987. Available at [http://insects.ummz.lsa.umich.edu/ beemites/Species_Accounts/Pyemotidae.htm]. Accessed June 15, 2007. 